\title{
Review on Macronutrient in Agronomy Crops
}

Isreal Zewide and Melash W.

Department of Natural Resource Management, College of Agriculture, Mizan-Tepi Unversity and Natural Resource Management, P,O.Box 260, Mizan-Aman, Ethiopia.

*Corresponding Author: Isreal Zewide, Department of Natural Resource Management, College of Agriculture, Mizan-Tepi Unversity and Natural Resource Management, P,O.Box 260, Mizan-Aman, Ethiopia.

\section{Received date: July 21, 2021; Accepted date: August 14, 2021; Published date: August 25, 2021}

Citation: Isreal Zewide and Melash W. (2021). Review on Macronutrient in Agronomy Crops. J. Nutrition and Food Processing, 4(6); DOI:10.31579/2637-8914/062

Copyright: () 2020 Isreal Zewide, This is an open access article distributed under the Creative Commons Attribution License, which permits unrestricted use, distribution, and reproduction in any medium, provided the original work is properly cited.

\begin{abstract}
Macronutrients play a very important role in plant growth and development. Three main elements are nitrogen, phosphorus, and potassium (N, P, K) and are required in abundance. They must be readily available through soil medium or fertilizer. The secondary elements are sulfur, calcium, and magnesium ( $\mathrm{S}, \mathrm{Ca}, \mathrm{Mg}$ ). The problem of low soil fertility and poor plant nutrition does not only affect crop yields but also crop quality. Various nutrient elements influence biochemical processes and eventually affect the overall quality of various crops and their products. Depending on the amount that is available for plant uptake, these nutrients influence crop yields and quality and plants treated with absence of nutrients in the nutrient solution showed that $\mathrm{N}$ and $\mathrm{Ca}$ were the most limiting nutrients to biomass production The crop quality characteristics mostly reported to be affected by plant nutrition include: proteins, carbohydrate, sucrose and fructose content in grains, root crops, tuber crops and fruits; vitamins like beta-carotene content in fruits and tubers; moisture content at storage in cereal grains, potato tuber density; and frying colours, and fruit weight. It has been noted that essential and beneficial nutrient elements contribute to crop quality through functioning as raw materials for the synthesis of various plant components that have food value to humans and animals.
\end{abstract}

Keywords: plant growth; yield; quality; nutrient content; glucosinolate; ATP; potato; amino acids; cowpea plants

\section{Introduction}

Plant growth is influenced by a number of factors including temperature, available water, light and available nutrients in the soil. A German scientist Justus von Liebig in the mid19th century was one of the first scientists to show that nutrients are essential for plant growth. Studies show that there are over 100 chemical elements but research has determined 17 nutrients that are also called essential elements [9]. Out of the 17 essential elements carbon $(\mathrm{C})$, hydrogen $(\mathrm{H})$ and oxygen $(\mathrm{O})$ are the non mineral nutrients because they are derived from the air and water. The remaining 14 mineral nutrients include six macronutrients: nitrogen $(\mathrm{N})$, phosphorus $(\mathrm{P})$, potassium $(\mathrm{K})$, calcium $(\mathrm{Ca})$, magnesium $(\mathrm{Mg})$, and sulphur (S); and eight micronutrients: boron (B), chlorine $(\mathrm{Cl})$, copper $(\mathrm{Cu})$, iron $(\mathrm{Fe})$, manganese $(\mathrm{Mn})$, molybdenum (Mo), nickel $(\mathrm{Ni})$ and zinc (Zn) [2]. Other nutrients that do not fall within the list of 17 essential elements but are needed in specific cases are referred to as beneficial elements. Each of the nutrients is needed in different amounts and carries specific functions in the plant. Depending on the amount that is available for plant uptake, these nutrients influence crop yields and quality [6] and plants treated with absence of nutrients in the nutrient solution showed that $\mathrm{N}$ and $\mathrm{Ca}$ were the most limiting nutrients to biomass production in cowpea [11]. Plants subjected to S deficiency had. Nutrients obtained from crops and crop products, for example nitrogen, sulphur and phosphorus, are constituents of various types of proteins and protein enzymes, which are important for building plant tissues and activating various metabolic processes respectively [10]. However, for the last three decades, crop nutrition research in sub-Saharan Africa (SSA), especially under continuous cropping without nutrient replenishment has largely focused on macronutrients, i.e., nitrogen, phosphorus, and potassium (Vanlauwe et al., 2015).

\section{Literature review}

\section{Types of nutrient}

\subsection{Nitrogen}

Plants require $\mathrm{N}$ in the largest amount among the three major/primary nutrients (others being $\mathrm{P}$ and $\mathrm{K}$ ). It has many functions including: promotion of rapid growth, increasing leaf sizes and quality, enhancing fruit and seed development; forms an integral component of many important components in plants including amino acids that are building blocks of proteins and enzymes, that are involved in catalyzing most biochemical processes. Thus, it plays a role in almost all metabolic processes. As determined by its functions $\mathrm{N}$ influences the rate of crop growth and crop quality. It increases the plumpness of the cereal grains, the protein content of both seeds and foliage, and the succulence of crops such as lettuce and radish. Increased protein 9780 content and physical grain quality in maize and rice with increasing $\mathrm{N}$ application has been 
reported in a good number of studies [1]. Nitrogen can also reduce crop quality and amount of $\mathrm{N}$ applied has been reported to influence potato (Solanum tuberosum) tuber quality. Potato processing quality factors include tuber solids and tuber density. Significant decreases in potato tuber specific gravity. Lower tuber specific gravity and high amount of reducing sugars such as fructose are considered as indicators of low quality. Increasing available $\mathrm{N}$ or $\mathrm{N}$ application has also been reported to reduce oil content in some legumes such as soybean and groundnuts. Sufficient amount of $\mathrm{N}$ availability in plants is required, because it is one of the major key factors of crop production [12].

\section{Deficiency Symptoms}

$\checkmark \quad$ Lack of $\mathrm{N}$ causes the reduction in chlorophyll production resulting into yellowing of lower leaves.

$\checkmark \quad$ In case of severe deficiency, spots appear on the tips and edges of leaves towards midribs and cause stunting.

$\checkmark \quad$ Nitrogen deficient plants always remain small in size and early flowering and fruiting takes place which mean the plant goes early in the reproductive phase.

$\checkmark \quad$ In this situation, the plant-yield and quality affect negatively.

$\checkmark \quad$ Nitrogen can be found in many inorganic forms

\begin{tabular}{|l|l|l|}
\hline Species & Name & Oxidation State \\
\hline $\mathrm{R}-\mathrm{NH}_{2}$ & Organic nitrogen, urea & -3 \\
\hline $\mathrm{NH}_{3}, \mathbf{N H}_{4}^{+}$ & Ammonia, ammonium ion & -3 \\
\hline $\mathrm{N}_{2}$ & Nitrogen & 0 \\
\hline $\mathrm{N}_{2} \mathrm{O}$ & Nitrous oxide & +1 \\
\hline $\mathrm{NO}$ & Nitric oxide & +2 \\
\hline $\mathrm{HNO}_{2}, \mathrm{NO}_{2}^{-}$ & Nitrous acid, nitrite ion & +3 \\
\hline $\mathrm{NO}_{2}$ & Nitrogen dioxide & +4 \\
\hline $\mathrm{HNO}_{3}, \mathbf{N O}_{3}^{-}$ & Nitric acid, nitrate ion & +4 \\
\hline
\end{tabular}

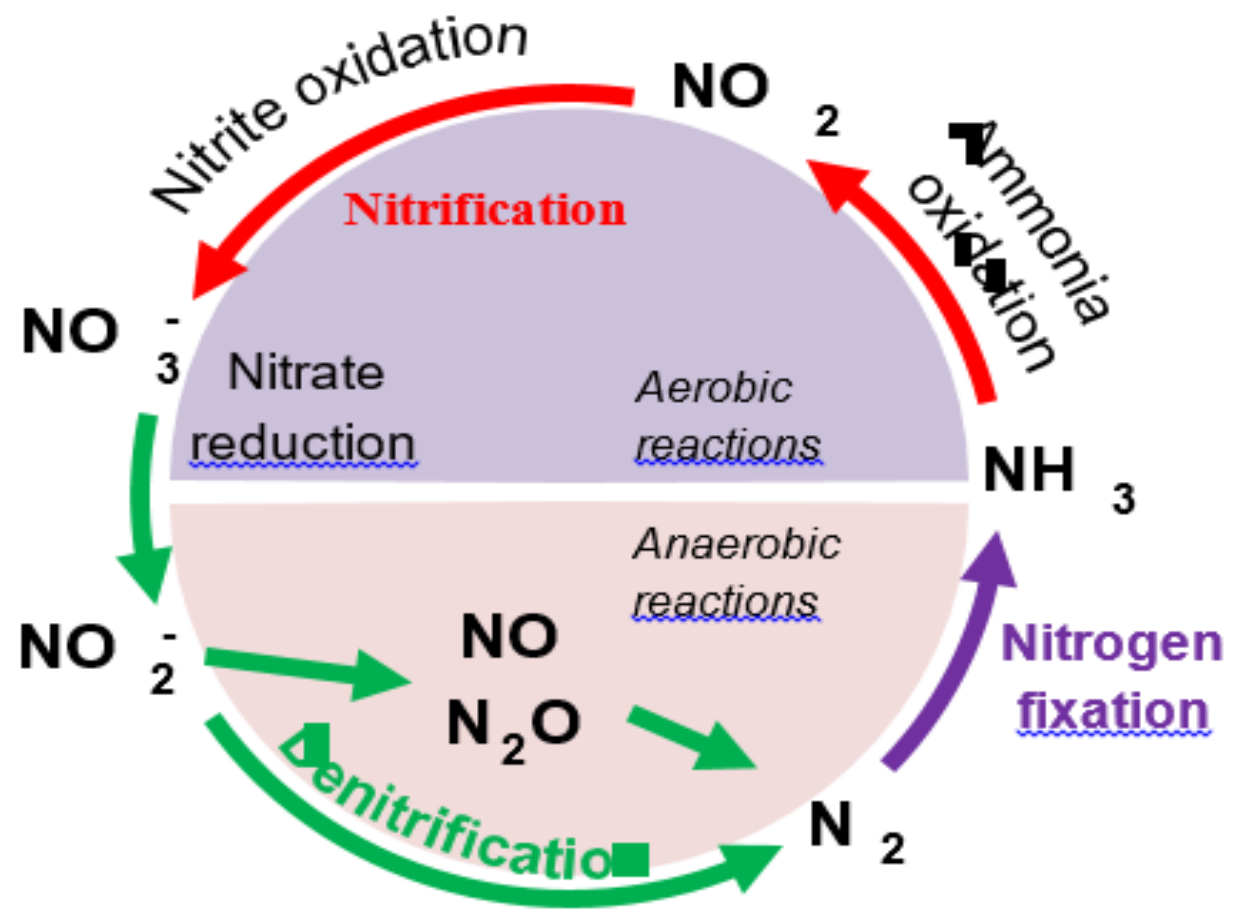

Figure. Sours, Adapted from Robertson, G.P. and Vitousek, P.M. (2009).

\subsection{Phosphorus}

Phosphorus is a very important macronutrient involved in most growth processes. It is an essential component of most organic compounds in the plant including nucleic acids, proteins, phospholipids, sugar phosphates, enzymes and energy-rich phosphate compounds, a common example being adenosine triphosphate (ATP). It improves crop quality in a number of ways including: reduced grain moisture content, winter hardiness, increased sugar content, increased protein content, increased P content, increasing proportion of marketable yields, better feed value, and improved drought and disease resistance in crops such as wheat and maize [6]. Synergistic effect is one of the factors that increases crop quality as far as $\mathrm{N}$ and $\mathrm{P}$ application are concerned. Application of $40 \mathrm{Kg} \mathrm{P}$ ha-1 increased $\mathrm{N}$ and $\mathrm{K}$ accumulation in the maize grain by $22.5 \%$ and $21.2 \%$ respectively [7]. 


\section{Deficiency Symptoms}

$>$ The leaves of plants turn blue or purple and stunting occurs due to deficiency of phosphorus.

$>$ Root-development of crop-plants inhibits due to $\mathrm{P}$ deficiency.

$>$ Its deficiency causes delay and reduction in flowering and fruiting.

$>$ Crop takes much time to ripe.

$>$ It affects the shape and size of fruits.

\subsection{Potassium}

Potassium is an essential nutrient that is absorbed by plants in larger amounts than any other nutrient except N (Roy 2006). Unlike N, P and most other nutrients, $\mathrm{K}$ is not incorporated into structures of organic compounds; instead potassium remains in ionic form $(\mathrm{K}+)$ in solution in the cell and acts as an activator of many cellular enzymes. Therefore, it has many functions in plant nutrition and growth that influence both yield and quality of the crop. These include regulation of metabolic processes such as photosynthesis; activation of enzymes that metabolize carbohydrates for synthesis of amino acids and proteins; facilitation of cell division and growth by helping to move starches and sugars between plant parts. It is reported that among the many plant mineral nutrients potassium $(\mathrm{K})$ stands out as a caption having the strongest influence on quality attributes that determine fruit marketability, consumer preference, and the concentration of critically important human-health associated phyto-nutrients or bioactive compounds (ascorbic acid and Beta carotene) [10]. Some more examples where fruit quality increased due $\mathrm{K}$ application. All the increase in quality as describe in this section can be attributed to the involvement of $\mathrm{K}$ in synthesis and movement of different products to their sinks. A condensed review on the effect of $\mathrm{K}$ on fruits and vegetable quality had been published.

\section{Deficiency Symptoms}

* In deficient plants, the height of plant is negatively affected and plant remains short.

* Due to $\mathrm{K}$ deficiency the tips and edges of leaves become burned.

* There is a reduction in sweetness and juice of fruits occurs in $\mathrm{K}$ deficient plants.

* Lack of potassium causes the water stress in light drought conditions.

* Due to K deficiency breaking of branches and lodging of crop plants will takes place.

\subsection{Sulphur}

Sulphur is the most abundant element in the earth's crust. It is absorbed by plants as Sulphates (SO42-). It is required for synthesis of S containing amino acids cystine, cysteine and methionine which are building blocks of proteins and is an important constituent of vitamins and hormones [15]. It is responsible for the formation of the disulphide bond between cysteine residues that help to stabilize the tertiary structure of proteins. It is also needed in the synthesis of coenzyme A and chlorophyll. The deficiency of $\mathrm{S}$ leads to accumulation of non-protein $\mathrm{N}$ such as NO3- and amine (NH2). Sulphur deficiency has been reported to lead to accumulation of NO3- in vegetables which is dangerous as these lead to fatal conditions such as methemoglobinemia in infants and formation of cancer inducing nitrosamines. This could be attributed to the role of $\mathrm{S}$ in protein synthesis in which is used as an essential component of amino acids and also the balanced fertilization that lead to the general high performance of the crop including synthesis of all $\mathrm{N}$ containing compounds such as proteins, chlorophyll and nucleic acids. An increase in glucosinolates, sulphur rich metabolites of the order Brassicales in the range of $25 \%$ to more than $50 \%$ with sulphur fertilization was also reported (Falk, 2007).
Glucosinolates are important in the defence of the plant against pests and pathogens.

They are also important for humans as a flavour component, cancer prevention agent and crop bio-fumigants, making them a good quality characteristic in these plants.

Evidence for glucosinolate catabolism has come from labeling studies. Sulphur application has been reported to increase the quality characteristic such as pungent smell in onions [13].

\subsection{Calcium}

Calcium is used in large amounts by plants second only to $\mathrm{N}$ and $\mathrm{K}$. It is a major component of the middle lamella (Ca-pectates) of the cell wall. It strengthens the cell walls, is involved in cell elongation and division, membrane permeability, and activation of several critical enzymes (Brady and Weil, 2008). It is important in $\mathrm{N}$ metabolism and protein formation by enhancing NO3- uptake and it is also important in translocation of carbohydrates and other nutrients. In accordance with its functions, calcium influences crop and food quality. Calcium is less mobile such that its influence on crop quality is easily noted with foliar application. Seven fold calcium foliar application also improved some fruit quality characteristics of 'Sinap Orlovskij' apple such as fruit calcium content (high quality) increased by $50-150 \mathrm{mg} / \mathrm{kg}$ and decreased bitter pit incidence (poor quality) by two times as compared with the control in Lithuania.

\subsection{Magnesium}

Magnesium is another secondary nutrient element. It is important as a primary constituent of chlorophyll and as a structural component of ribosomes, it helps in their configuration for protein synthesis. It is also required for maximum activity of almost all phosphorylating enzymes in carbohydrate metabolism. Adequate levels of $\mathrm{Mg}$ in USA reported increased quality and profits of potato due to improved potato specific gravity (Hoyum 2000). Increased specific gravity of potatoes can be attributed to increased carbohydrate synthesis and deposition from the leaves. Usually, the first things to be noticed due to influence of $\mathrm{Mg}$ are chlorophyll level, photosynthesis (photosynthetic CO2 fixation), and protein synthesis, however, recently, distribution of carbohydrates among shoot and root organs have been reported as well. These in turn affect quality of plant product depending on which part is used for food by humans or animals. A four-fold increase of sucrose in leaves of Mgdeficient sugar beets compared to the $\mathrm{Mg}$-adequate sugar beet plants was reported and this affected quality of Mg-deficient sugar beets [5]. This was attributed to inhibition of sucrose/sugar distribution from leaves to root organs in the Mg-deficient plants.

\section{Symptoms}

The initial symptoms of nitrogen deficiency were characterized by the light-yellow green color of mature leaves, which caused a reduction on the development of the plants (Figure 1a). This nutrient is the main constituent of proteins, nucleic acids, phytohormones, and secondary metabolites (Malavolta, 1980), especially the chlorophyll, which is a green-color pigment that is indispensable for the photosynthesis process. The plants subjected to $\mathrm{P}$ deficiency presented visual symptoms such as narrow leaf insertion angle, opaque dark green color, low vegetative development, and leaves with homogeneous distribution of chlorotic points in the internerval regions followed by necrosis, and upward curved edges (Figure 1b). These symptoms were also observed by [11] in cowpea plants. Potassium was the nutrient that caused the third greatest reductions in the vegetative growth of cowpea, after $\mathrm{N}$ and $\mathrm{Mg}$. The symptom of potassium deficiency in the plants consisted of mature leaves becoming opaque green, with dark punctures in the borders of the leaf limbs, followed by chlorosis, and intense necrosis (Figure 1c). These symptoms 
were due to the functions of $\mathrm{K}$ in the plant, especially the osmotic potential regulation, and enzymatic activation (Malavolta, 2006). The necrosis in the leaf edges shows the water unbalance of the plant, which is initially seen in the region where most of the stomata are concentrated.

Plants growing in the absence of Ca were the first to show characteristic symptoms wrinkled and upward curved edges of young leaves, dark punctures throughout the leaf limbs, and chlorosis progressing to necrosis. The leaves appeared to be thick and brittle and presented intense green opaque color (Figure 1d); moreover, they were easily detached from the stem. The same symptoms were observed by [11] in cowpea plants. The symptoms of these plants were characteristic of Ca deficiency, due to its main functions in the plant, since it is a nutrient with little mobility, and binds to polysaccharides in the cell wall (Malavolta 2006); therefore, the symptoms were more pronounced in meristematic regions.
The symptoms of $\mathrm{Mg}$ deficiency were poor leaf formation, with irregular borders, and marked internal chlorosis. The hypothesis that explains this result is that the absence of $\mathrm{Mg}$ causes a higher $\mathrm{K}$ uptake due to the antagonistic interaction between these nutrients; the higher concentrations of $\mathrm{K}$ in the plant possibly increased the $\mathrm{K}$ to $\mathrm{N}$ ratio and consequently increased synthesis of soluble compounds of low molecular weight that favored the attack of pests and diseases to the plants [16].

The absence of $\mathrm{S}$ in the nutrient solution caused no significant effects on vegetative growth parameters and the plants showed no symptoms of deficiency during their initial growth (Figure 1f). However, [11] evaluated nutritional deficiencies of macronutrients in cowpea seedlings and observed visual symptoms of sulfur deficiency on the eleventh day of experiment.
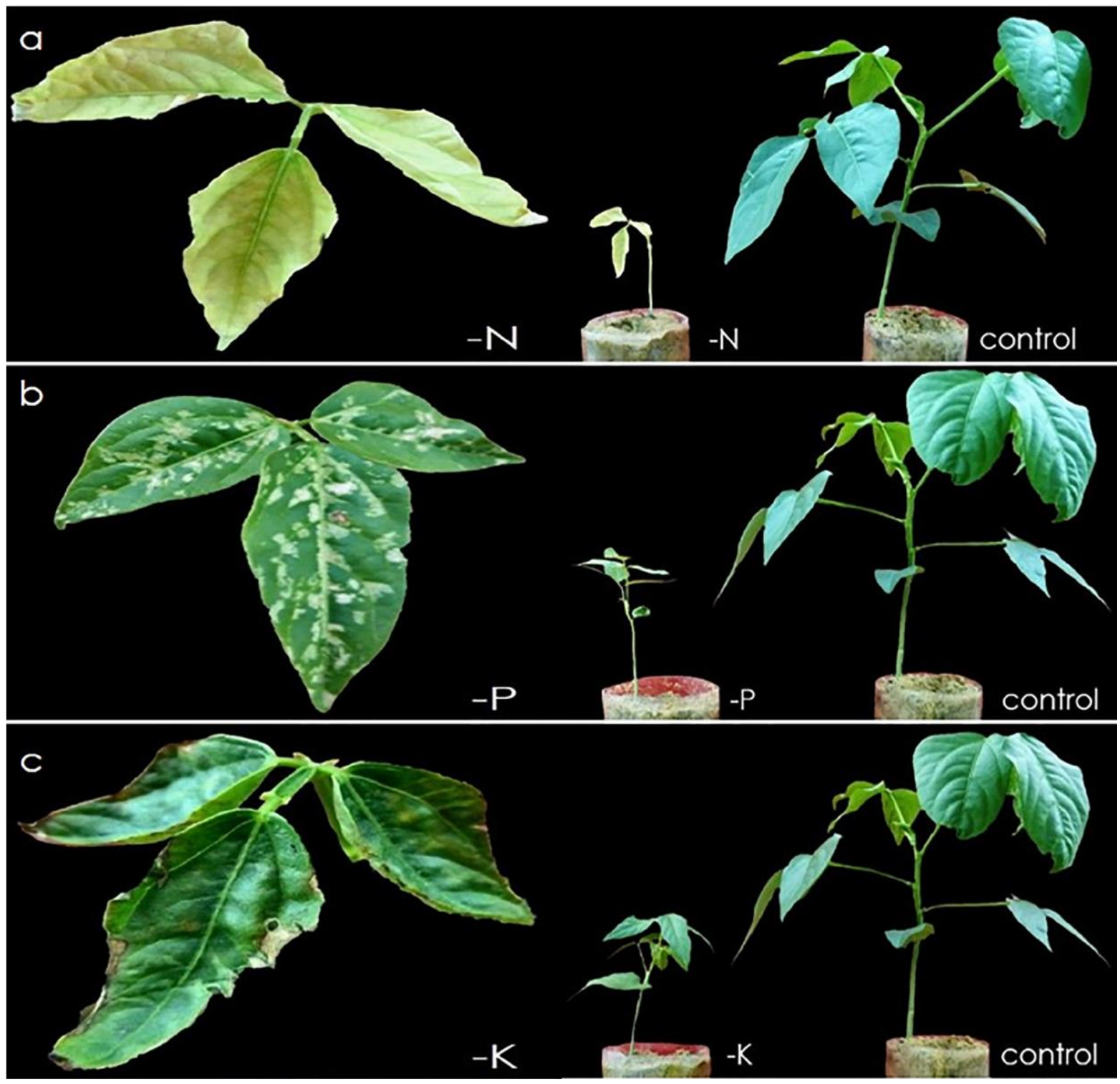

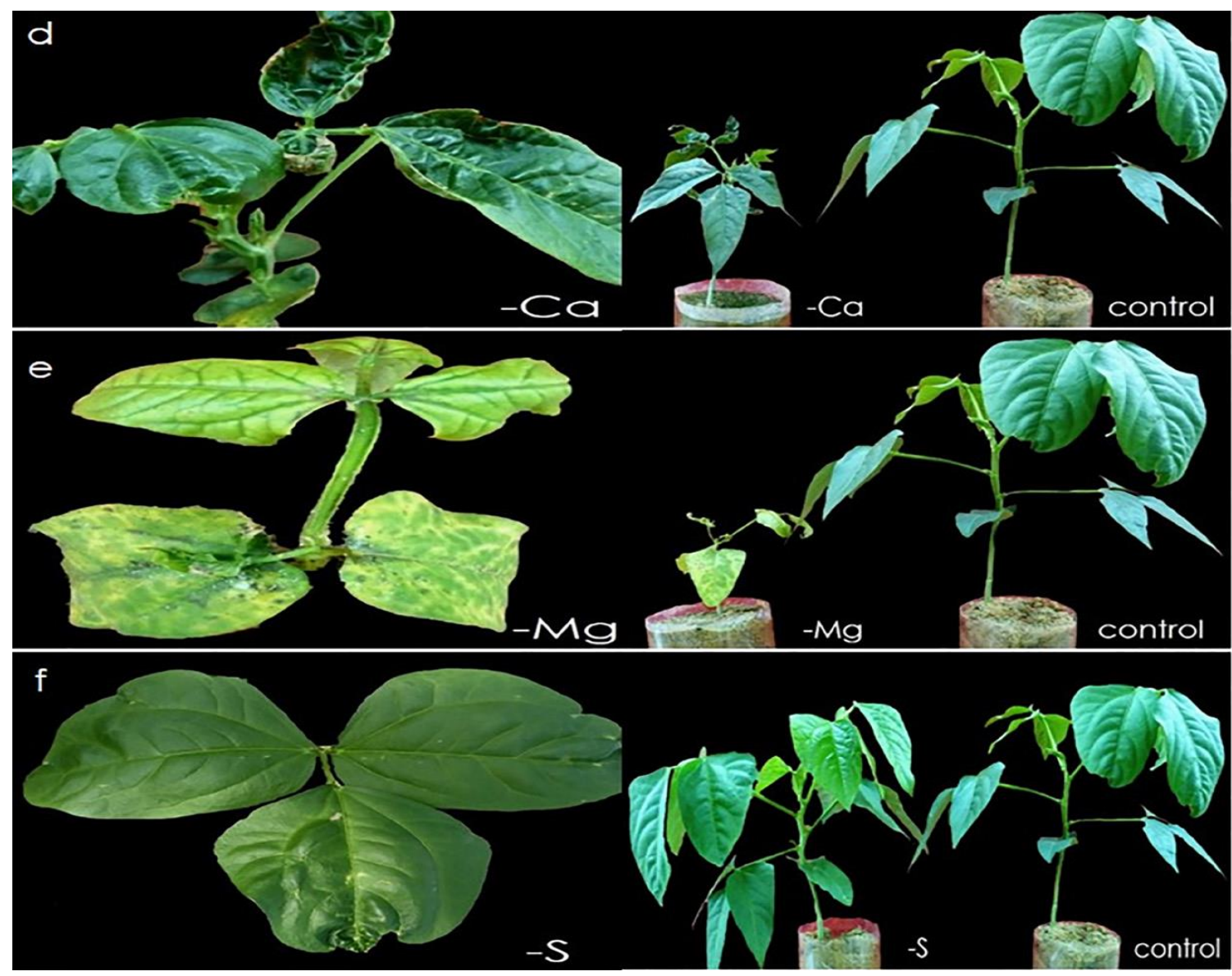

Figure 1. Symptoms of nitrogen (a), phosphorus (b), potassium (c), calcium (d), magnesium (e), and sulfur ( $f$ ) deficiencies in cowpea plants of the BR17-Gurguéia cultivar [18].

The absence of any of the macronutrients, except S, decreased the shoot, root, and total dry weights. The low biomass production of the plants is probably connected to the growth parameters, since they show the limitations of the initial growth caused by nutrient deficiencies. Studies on plants treated with absence of nutrients in the nutrient solution showed that $\mathrm{N}$ and $\mathrm{Ca}$ were the most limiting nutrients to biomass production in cowpea [11].

\section{Nutrient uptake}

The pattern of nutrient uptake follows a sigmoid (S-shaped) curve in most cases, being first low in the early stages of crop growth, increasing rapidly when dry matter production is maximal and then declining towards crop maturity. During vegetative growth, the daily nutrient uptake increases as growth progresses and reaches a maximum during the main growing period.

$\mathrm{N}, \mathrm{P}$ and $\mathrm{K}$ are mainly taken up during active vegetative growth for high photosynthetic activity. The rate of $\mathrm{N}$ uptake generally exceeds the rate of dry matter production in the early stages. Phosphate has an additional small peak requirement for early root growth. Modern high-yielding grain varieties continue to absorb $\mathrm{P}$ close to maturity and, like $\mathrm{N}, 70-80$ percent of absorbed $\mathrm{P}$ ends up in the panicles or ear heads. For fast-growing crops and high yields, the daily nutrient supply must be adequate, especially during the period of maximum requirement.

Field crops generally absorb $\mathrm{K}$ faster than they absorb $\mathrm{N}$ and $\mathrm{P}$. In rice, 75 percent of the $\mathrm{K}$ requirement of the plant may be absorbed up to boot leaf stage. Between tillering and panicle initiation, mean daily absorption rates can approach $2.5 \mathrm{~kg}$.

\section{Essential Elements for Crop Growth}

Fifteen chemical elements are considered essential for plant growth, that is, plants will not complete their life cycle if they are not supplied. Each of these essential elements has defined physiological functions that have been described by Mengel and Kirkby (1987). The composition of a normal plant in terms of these elements essential for plant growth is given in Table 2. which also includes oxygen, carbon and hydrogen although these are not normally grouped as nutrients. These are supplied from oxygen and carbon dioxide in the air and water respectively. The nutrients are grouped according to the quantity required for production. Macronutrients are needed in concentrations greater than $0.15 \%$ of dry matter or are present at greater than $5 \mathrm{~kg} / \mathrm{ha}$ in the mature plant tops.

Table 2. gives an indication of the average concentrations of elements in crops, the forms taken up, and the quantity of nutrients within plant tops. In particular, Table 2. shows that crops remove large quantities of $\mathrm{N}$ and $\mathrm{K}$ in the harvested products, especially those taken for hay. Examples of $\mathrm{P}$ removal at harvest by other crops (kg/t product) are maize 3.3, sorghum 3.7, rice 2.9, field pea 4.9, and cowpea 6.9 (Glendinning, 2000). Some plant species may require other elements for growth. Sodium may be necessary for plants with the $\mathrm{C} 4$ photosynthetic pathway and some halophytes such as saltbush (Atriplex spp.). Silicon is important for the strength of stem tissue of some crops such as rice (Savant et al., 1997) and sugarcane. Legumes fixing N symbiotically require cobalt. 


\begin{tabular}{|c|c|c|c|c|c|}
\hline \multicolumn{6}{|c|}{ Nutrient yield/ha to grow } \\
\hline Element & $\begin{array}{l}\text { Average element } \\
\text { composition }(\%)\end{array}$ & $\begin{array}{l}\text { Lucernce (hay } \\
\text { yield of } 10 \mathrm{t} / \mathrm{ha}) \\
\text { per year }(\mathrm{kg})\end{array}$ & $\begin{array}{l}\text { Wheat } \\
7 \mathrm{t} \text { straw } \\
(\mathrm{kg})\end{array}$ & $\begin{array}{l}4 \mathrm{t} \text { grain } \\
(\mathrm{kg})\end{array}$ & $\begin{array}{ll}\begin{array}{l}\text { Ionic } \\
\text { adsorbed }\end{array} & \text { form } \\
\end{array}$ \\
\hline \multicolumn{6}{|c|}{ Macronutrient } \\
\hline s & $3-5$ & 350 & 50 & 80 & $\mathrm{NH}_{4}^{+}, \mathrm{NO}_{3}^{-}$ \\
\hline $\mathrm{N}$ & $0.2-0.6$ & 35 & 5 & 14 & $\mathrm{H}_{2} \mathrm{PO}_{4}^{-}$ \\
\hline $\mathrm{P}$ & $2-4$ & 200 & 42 & 17 & $\mathrm{~K}^{+}$ \\
\hline K & $0.2-0.4$ & 35 & 8 & 10 & $\mathrm{SO}_{4}^{2}$ \\
\hline $\mathrm{S}$ & $0.2-3.0$ & 100 & 20 & 8 & $\mathrm{Ca}^{2+}$ \\
\hline $\mathrm{Ca}$ & $0.1-0.3$ & 30 & 5 & 6 & $\mathrm{Mg}^{2+}$ \\
\hline $\mathrm{Mg}$ & & & & & \\
\hline
\end{tabular}

Table 2. Concentrations and yields of nutrients in crops and the form absorbed by plants.

\section{Balanced Nutrition and Nutrient Interactions}

As a balanced diet is required for a human body so is it required by the plant, and this has an implication on crop quality. For instance, the ratio of $\mathrm{N}: \mathrm{S}$ is very critical for the synthesis of proteins. Research shows that most crops attain optimal protein synthesis with $\mathrm{N}: \mathrm{S}$ ratio within 15:1 [8]. Nutrient interactions may be synergistic where a positive effect is enhanced by balanced application of the two nutrients as the case of $\mathrm{N}$ and $\mathrm{S}$ or antagonistic where an increase in one nutrient reduces uptake and function of the other and eventually reducing crop quality. For instance, the rate of $\mathrm{Mg}$ uptake can be depressed by $\mathrm{Ca}$ and vice versa [3]. This is attributed to the competitiveness of $\mathrm{Ca}$ with $\mathrm{Mg}$ whereby the root plasma membrane binding sites have the higher affinity to $\mathrm{Ca}$ than to $\mathrm{Mg}$. A decreased yield of marketable tomato fruits was reported when $\mathrm{Ca}: \mathrm{Mg}$ ratio was less than one. Plant uptake and utilization of $\mathrm{Zn}$ is reduced by the available or applied P. On the other hand increase in $\mathrm{N}$ fertilizer is reported to increase $\mathrm{Zn}$ uptake and utilization [4].

\section{Soil mineral matter}

The soil mineral matter ranges from large pieces of gravel, pebbles and nodules to small grains of sand, silt and clay particles. In addition, there are various oxides, sulphates, silicates and carbonates. The mineral matter on the earth's surface is made up largely of oxygen (47 percent) and $\mathrm{Si}$ (28 percent). Only eight elements are present in amounts greater than 1 percent. Among the plant nutrients, the most abundant are not $\mathrm{N}$ or $\mathrm{P}$ but $\mathrm{Fe}, \mathrm{Ca}, \mathrm{K}$ and $\mathrm{Mg}$. While all the mineral fractions determine the texture and water holding capacity (WHC) of a soil, the sand fraction does not do much. The silt acts as a storehouse of certain nutrients, such as $\mathrm{K}$, while the clay fraction is the most active and a class by itself. Some common minerals formed in soils are listed below on the basis on their degree of solubility (Bolt and Bruggenwert, 1976).

Saturated solutions of salts with a high solubility inhibit plant growth because of high osmotic pressure. These salts in solid phase are only present in significant quantities under exceptional circumstances (e.g. deserts and in saline or sodic soils). Minerals of intermediate solubility are those with a saturated solution not inhibiting plant growth but their solubility is high enough to contribute significantly to the nutrient composition of the soil solution.

\section{Soil organic matter}

Most soils are of mineral origin, but their topsoil contains organic matter that, in spite of its low content, is of great importance to many aspects of soil fertility and plant growth. Soil organic matter (SOM) can range from less than 1 percent in many tropical arid and semi-arid soils of the plains to 5 percent or more in temperate regions or under forest vegetation. The average composition of SOM is 47 percent $\mathrm{C}, 44$ percent $\mathrm{O}, 7$ percent $\mathrm{H}$, 2 percent $\mathrm{N}$ and very small amounts of other elements. More than half of SOM consists of carbohydrates, 10-40 percent is the resistant material lignin and the rest consists of compounds of N. SOM or "humus" reaches equilibrium during soil formation. Wet and/or cold soil conditions tend to increase the humus content, whereas high temperatures of tropical climates and cropping procedures promote its decomposition. The C:N ratio provides a general index of the quality of SOM, being in the range of 10-15:1 for fertile soils. When organic manures or green manures are added, these become a part of the organic

\section{Conclusion}

Nitrogen, phosphorus, potassium, calcium, and magnesium were the most limiting nutrients for the vegetative growth and biomass production. The absence of these elements in the nutrient solution caused morphological changes and visual symptoms that are characteristic of nutritional deficiency of these nutrients. All nutrient elements focused in this study influence crop quality. This is manifested by changes or differences in quality attributes of different crops with different rates of nutrient elements applied or available to various crops. Crop yields, crop quality is another area that needs to be considered with serious attention as it affects human nutrition and profitability of crop products. It is recommended that research in soil fertility and plant nutrition take a multidisciplinary approach where soil scientists, breeders and human nutrition.

\section{References}

1. Blumenthal, J., Battenspenrger, D., Cassman, K.G., Mason, K.G., Pavlista, A., (2008). Importance of nitrogen on crop quality and health.

2. Brady NC and RR Weil (2008).The Nature and Properties of Soils.

3. Hao X and AP (2003). Papadopoulos Effect of calcium and magnesium on growth, fruit yield and quality in a fall greenhouse tomato crop grown on rockwool.

4. Hafeez, B., Khanif, Y.M., Saleem, M., (2013). Role of zinc in plant nutrition.

5. Hermans, C., Johnson, G.N., Strasser, R.J., Verbruggen, N., (2004). Physiological characterization of magnesium deficiency in sugar beet: acclimation to low magnesium differentially affects photosystem, 220(2):344-355.

6. Havlin, J.L., Beaton, J.D., Tisdale, S.L., Nelson, W.L., (2005). Soil Fertility and Fertilizers: An Introduction to Nutrient Management.

7. Hussaini, M.A., Ogunlela, V.B., Ramalan, A.A., Falaki, A., (2008). (Mineral compostion of dry season maize (Zea mays L.).

8. Jamal, A., Moon, Y., Abdin, M.Z., (2010). Sulphur- a general overview and interaction with nitrogen.

9. Jones, C., Jacobsen, J, 2001. Plant nutrition and soil fertility. Nutrient Management Extension Publication. Montana State University. 
10. Lester, G.E., Jifon, J.L., Makus, D.J., (2010). Impact of potassium nutrition on postharvest fruit quality: melon (Cucumis melo L.) Case study.

11. Miranda, R.S., Suderio, F.B., Marques, E.C., Gomes Filho, E. (2017). Accumulation and partition of $\mathrm{Fe}, \mathrm{Zn}, \mathrm{Cu}, \mathrm{Mn}$ and $\mathrm{Na}$ in macro and micro nutrientdeficient cowpea plants 7(2), 10361043.

12. Nadeem, S.M., Ahmadb, M., Zahir, Z.A., Javaid, A., Ashraf, M., 2013. The role of mycorrhizae and plant growth promoting rhizobacteria 3 (PGPR) in improving crop productivity under stressful environments 32(2):429-448.

13. Randle, W.M. 1992. Onion germplasm interacts with sulphur fertility for plant sulphur utilization and bulb pungency 59, $151-156$.
14. Soetan, K.O., Olaiya, O.C., Oewole, O.E., (2010). The importance of mineral elements for humans, domestic animals and plants 4(5), 200-222.

15. Sylvia DM, Furhmann JJ, Hartel PG and DA Zuberer (2005). Principles and Application of Soil Microbiology.

16. Seabra Júnior, S., Lalla, J.G., Goto, R., Maringoni, A.C., Villas Boas, R.L., Rouws, J.R.C., Oriani, E.E., (2013). Susceptibility to black rot and broccoli yield as a function of nitrogen and potassium doses.

17. Tucker, M.R., (1999). Essential plant nutrients: their presence in North Carolina soils and role in plant nutrition. Agronomic Division.

18. Flávia Louzeiro de Aguiar Santiago, Franklin Eduardo Melo Santiago, José Ferreira Lustosa Filho, Rafael Felippe Ratke. (2018). Plant growth and symptomatology of macronutrient deficiencies in cowpea plants.
This work is licensed under Creative Commons Attribution 4.0 License

\section{To Submit Your Article Click Here: Submit Manuscript}

DOI: $10.31579 / 2637-8914 / 062$
Ready to submit your research? Choose Auctores and benefit from:

$>$ fast, convenient online submission

$>$ rigorous peer review by experienced research in your field

$>$ rapid publication on acceptance

$>$ authors retain copyrights

$>$ unique DOI for all articles

$>$ immediate, unrestricted online access

At Auctores, research is always in progress.

Learn more auctoresonline.org/journals/nutrition-and-food-processing 